\title{
Társadalmi különbségek a Magyar Királyság központi területeinek 10-14. századi falusias településein
}

\author{
RÁCZTIBOR ÁKOS \\ Ferenczy Múzeum \\ H-2000 Szentendre, Fő tér 2-5., racz.tibor.akos@gmail.com
}

Rácz, T. Á.: Social differences within 10th-14th centuries rural settlement types in the central area of the Hungarian Kingdom Abstract: Present paper analyses some aspects of hierarchy within 10th-14th centuries villages, farms and intermediate forms of habitation using mainly the data of excavations and field surveys in Pest County.

Keywords: social hierarchy, settlement structure, formation of settlements, church

\section{Bevezetés}

A történeti falu jól körülhatárolható földrajzi térben fejezi ki egy kisebb emberi közösség adott korszakban jellemző birtokjogi, társadalmi, gazdasági, ökológiai viszonyait. Létrejötte és élete számtalan, párhuzamosan zajló folyamat eredménye. Nem csak egy házakkal fedett földterület, hanem időben és térben dinamikusan változó, organikus egység. A régészet az emberi életteret a maga teljességében próbálja rekonstruálni. Ez megköveteli, hogy ne csak a feltárt régészeti jelenségeket, vagy a közvetlen, természeti környezetet vizsgáljuk, hanem a lehető legtágabb értelemben vett történeti kontextust. Régészeti módszerekkel lehet kutatni többek közt azt is, hogy a földrajzi térben hogyan jelennek meg a társadalmi dimenziók, azaz, hogy a hierarchikus viszonyok hogyan befolyásolták a telepek, vagy temetők szerkezetét.

A társadalmi különbségek kérdésköréhez a kora középkor időszakára vonatkozóan hagyományosan a temetőkutatás adatait szokták kiaknázni. ${ }^{1}$ A honfoglaló magyarság társadalmi rétegződéséről kialakított elképzelésünk jelen pillanatban is leginkább temetőfeltárásokon nyugszik. A kereszténység felvételével megszűnik a mellékletadás szokása, és ezáltal a leletanyag által nyújtott rekonstrukciós lehetőségek is leszűkülnek. Az elhunytaknak immár a temetőn belüli pozíciója utal társadalmi rangjára, mintsem a velük eltemetett tárgyak. Érdekes azonosítási lehetőségek természetesen adódnak, de ezek inkább kivételszámba mennek. Így például minden bizonnyal papi temetkezésre utal a visegrádi főesperesi templom szentélye mögötti sírban talált 11. századi kehely és paténa, vagy a másik sírban talált vas vezeklőöv. ${ }^{2}$

Az államalapítás utáni írott források lehetővé tették az Árpád-kori társadalom rekonstruálását, de ennek a rendkívül színes világnak a régészeti hagyatékát nem sikerült még a társadalmi csoportok szerint differenciálni. Lehetséges-e a településrégészet adatainak társadalomtörténeti jellegű értelmezése? Az írott források alapján feltételeznünk kell, hogy a társadalmi elkülönülés az Árpád-korban meglehetősen éles volt, a különbségeknek pedig a külsőségekben is meg kellett nyilvánulniuk. A települések társadalmi összetételét lakóinak jogállása, vagyoni helyzete és birtokviszonyai határozták meg. Szerencsés esetben az írott források szolgáltatnak adatot néhány településre, de az Árpád-kori lelőhelyek túlnyomó többségében ezeket a segédleteket nélkülöznünk kell.

A későbbiekben gyarapszik a vonatkozó információk száma, de az Árpád-korban magában a leletanyagban, az építészeti megoldásokban, esetleg a településszerkezetben kell keresnünk a társadalmi elkülönülés jeleit. Falufeltárásaink azonban szinte kivétel nélkül lakói által felhagyott, kiürített telepnyomokat dokumentálnak. Ritkán bukkanunk kiemelkedő értéket képviselő leletcsoportra, presztízstárgyakra, vagy az átlagostól eltérő, összetett építészeti megoldásokra. Történeti forrásként kezelendők a kincsleletek, de értelmezésük során nem szabad elfelednünk, hogy speciális körülmények közt, krízishelyzetben válnak leletegyüttessé, sok esetben összefüggéseikből kiragadott tárgyak. Nehezen azonosíthatjuk az elrejtő társadalmi pozícióját, előkerülésük alapján nem ágyazhatjuk be őket településtörténeti összefüggések közé. Az aranyleletek inkább az elithez köthetők, az ezüst és a bronz viszont szinte bármelyik társadalmi csoporthoz.

Jelen tanulmány a társadalmi hierarchia szemszögéből vizsgálja meg a 10-14. századi falvakat, magányos háztartásokat és egyéb átmeneti megtelepedési formákat főleg Pest megyei feltárások és terepbejárások segítségével.

1 Steuer 1982.

2 Buzás - Mészáros 2008. 71-72. 


\section{Adatok a középkori településhálózat és a települések belső hierarchiájára}

A történeti adatok szerint az Árpád-kor első felében az arisztokrácia kisszámú volt. A király, a legnagyobb földtulajdonos, udvarával rendszeresen felkereste rezidenciáit. A társadalmi elit világi és egyházi központokban, újépítésű földvárakban, vagy újjáépített, római eredetű erődökben koncentrálódott, ahonnan a megyéket, püspökségeket ellenőrizték. ${ }^{3}$ Ezek a várak a központosított feudális hatalmat jelenítették meg, de nem csak adminisztratív és katonai létesítmények voltak, hanem lakófunkciót is betöltöttek. A politikai hatalom jelenlétét a megyeközpontok mellett az olyan preurbánus települési agglomerációkon is feltételezhetjük, melyek uralkodói, vagy egyházi birtokokon alakultak ki, és melyek az Árpád-kor második felétól váltak jogi értelemben is várossá. A földtulajdonosok főúri rezidenciájuk mellett majorságokat, praedium-nak nevezett gazdasági és raktárközpontokat birtokoltak, főleg szolgákból álló specializált munkaerővel. ${ }^{4} \mathrm{~A}$ prediális birtokközpontokban „palotáról", fallal körülvett épületekről is vannak adataink. ${ }^{5}$ A régészeti kutatás nem igazán tudta azonosítani ezt a településtípust, és nem tudott új adatokat szolgáltatni a majorság gazdálkodásának történeti fogantatású koncepciójához. A földesúr rezidenciája és a csatlakozó lakóépítmények alkották azt a településtípust, ahol a kézmúves termékek legnagyobb részét előállították, ahol a termékfölösleget felhalmozták, ahol az első templomokat felépítették és ahol idővel a piac első nyomai megjelentek. A településhierarchia alsó szintjén álltak a különböző kiterjedésű falusias települések az adókhoz és szolgáltatásokhoz kötött lakossággal. A törvény a falusias településeket egyenrangúan kezelte, megnevezésük minden esetben a villa.

Szent István törvényei ${ }^{6}$ a lakóépítményeknek már négy különféle megnevezését őrizték meg. Mégsem tarthatjuk ezeket biztosan létező típusoknak, hiszen a törvények szövegei néha szóról szóra alemann és bajor mintákat követtek. A curtis jelölhette a társadalmi elit udvarházát. Nem derül ki a különbség a domus és a mansio között, talán nem is volt, de mindkettőre úgy utalnak, mint ami könnyen felgyújtható, vagy elpusztítható. A legalacsonyabb rendű építmény, a mansiuncula, a közemberek lakhelye volt (,,Si vulgaris quidem alterius sui similis mansiunculas invaserit..."). Freisingi Ottó, aki III. Konrád keresztes hadjárata alkalmával a 12. század közepén megfordult a magyarok földjén feljegyezte, hogy házaik nádból, ritkábban fából, még ritkábban kőből épültek. Nyáron és ősszel sátrakban laktak.?

A társadalmi különbségek - amint fentebb utaltunk rá - az anyagi kultúrában, építéstechnikában és a falusias települések külső megjelenésében is tükröződhetnek. A települések belső szerkezete és maga a településhálózat, akárcsak a társadalmi, gazdasági berendezkedés nagy változásokon ment keresztül a 10-14. századok alatt. A hierarchia problémáját elemezve különbséget kell tennünk a 10. század, a kora, középső és késő Árpádkor, valamint a 14. század közt.

Az M0-s autópálya kiterjedt felületein feltárt mintegy 130 földbe mélyített építmény szórt településszerkezetet mutat. ${ }^{8} \mathrm{~A} 10$. században a házak a csatlakozó régészeti objektumokkal rendszerint egymástól pár száz méterre helyezkedtek el. Ezekre az izolált tanyákra még önálló települési egységként tekinthetünk. Egyetlen esetben, Vecsés 67. lelőhelyen alkottak házcsoportot. Később, a 11-12. században már a házcsoportok válnak jellemzővé, de sem méreteik, sem térbeli kapcsolataik nem mutatnak semmilyen szabályosságot. Csak a 13. századtól számolhatunk szabályos települési struktúrákkal, telkek és talán utcák nyomaival. Az Árpád-kori települések szórt jellegéből adódóan nehéz megjelölni határaikat és az azonos közösséghez tartozó háztartásokat, családokat. A szóban forgó időszakból területünkön nincsenek a határokat leíró okleveleink. Mivel nem tudjuk, hol végződik az egyik település és hol kezdődik a másik, nem tudjuk kategorizálni ezeket a formációkat még a méretük alapján sem, ezért az a törekvés, hogy meghatározzuk funkciójukat és súlyukat a településhálózatban jelenlegi adatainkkal nem lehetséges.

A magyar középkori régészetben a háztípusok kutatásának Méri lstván munkássága óta virágzó hagyománya van. ${ }^{9}$ Társadalmi kontextusban ezek az építmények egy-egy háztartásnak feleltethetők meg, gazdasági szempontból egy termelői egységet képeztek. Lakóinak jogi és társadalmi helyzete a mi eszközeinkkel nem mutatható ki. Társadalmi hierarchia tekintetében csak az építmények jellegzetességei és leletanyaga (leginkább kerámia) lehet kifejező. Az Árpád-kori falusi közösségek cölöpszerkezetes lakóépítményei ugyanazokat az építési elveket követték évszázadokig. A Pest megyében feltárt, egyosztatú, földbe mélyített lakóépítmények időrendi sorba állítva mutatnak bizonyos átalakulási tendenciákat, de alaprajzuk, külső megjelenésük, építéstechnikájuk, az építéshez felhasznált alapanyag alapján nem állíthatjuk, hogy lakóik eltérő társadalmi rétegbe tartoztak. Az Árpád-korban az építmények külső megjelenése egymáshoz nagyon hasonló, azoké is, melyek valamilyen ipari tevékenység, például kovácsolás egyértelmú bizonyítékait mutatják. Úgy túnik, hogy differenciálódásuk csak a késő középkor időszakában indul meg, legalábbis az általunk vizsgált régióban.

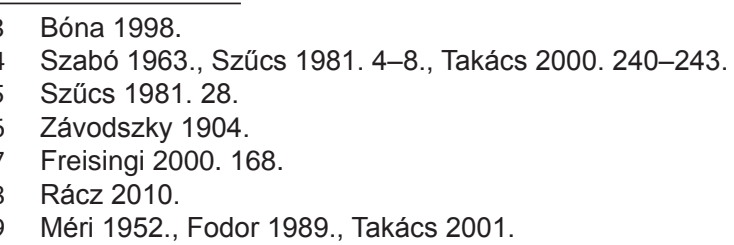




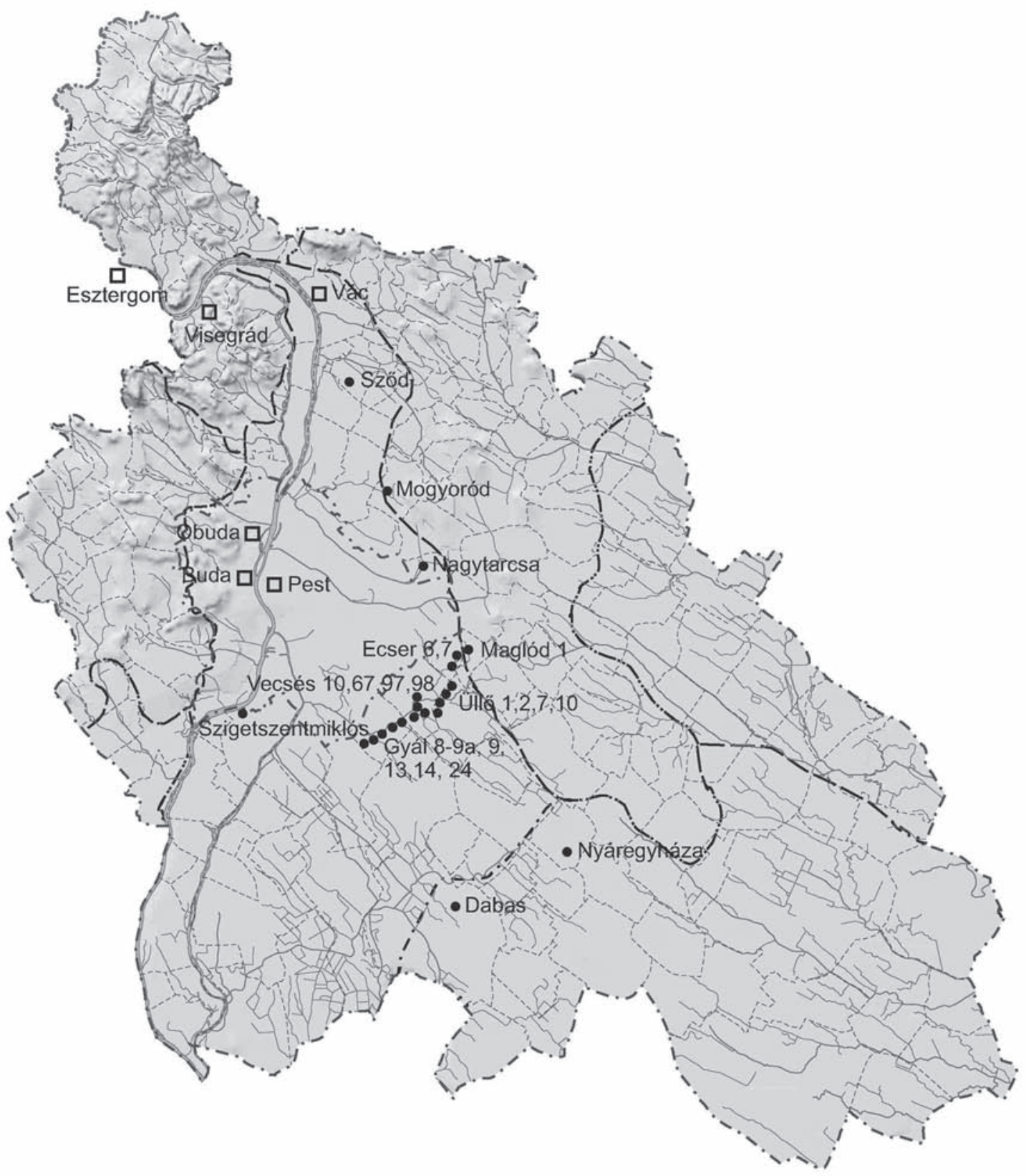

1. kép: Pest megye térképe az elmúlt 15 évben kutatott fontosabb Árpád-kori régészeti lelöhelyekkel. A négyzetek a királyi és egyházi központokat mutatják. (A tanulmány minden térképét Érdi Benedek készítette)

A házak szegényes leletanyaga általában háztartási kerámiából, kevés vas- és bronztárgyból, állatcsontokból tevődik össze. Mindössze Gyál 3. lelőhelyen került elő néhány grafitos anyagú kerámiatöredék és egy mázas bizánci(?) vagy balkáni(?) korsó, amely külföldi eredete és különleges minősége miatt egykori birtokosának kiemelkedő státuszára utalhat. Ez volt az egyetlen az M0-s autópálya 23 Árpád-kori lelőhelyéből, ahol a házaknak deszkapadlója volt, vagy legalábbis ahol sikerült ilyet dokumentálni. ${ }^{10} \mathrm{~A}$ fenti adatok alapján az általunk vizsgált területen fekvő telepnyomok, vagy inkább lelőhelyek egy kivételével azonos helyet foglaltak el a hierarchiában. A társadalmi csoportok írott forrásokból ismert változatossága mintaterületünk régészeti adataiban nem jelent meg.

10 Simonyi 2003. 
A vizsgált több száz éves perióduson belül Magyarország teljes területéről is csak szórványos adataink vannak a társadalmi elit jelenlétére falusias településeken. Wolf Mária a borsodi földvárban feltárt 10. századi településen azonosított egy kőalapozású építményt, feltehetően a közösség vezetőjének lakhelyét."1 Miklós Zsuzsa a Tura-Szentgyörgyparti 12. század végi - 13. század eleji, kétosztatú téglaépületet a falu birtokosának lakhelyeként értelmezte. ${ }^{12}$ Méri István szintén valószínűnek tartotta, hogy a kardoskúti, a 13. század első felében használt téglaépület a falu vezetőjének lakhelye volt. ${ }^{13}$ A Nagyvázsony melletti Csepelyen a 13. századi plébániatemplom romjai mellett egy többször átépített nemesi udvarházat és egy hozzá tartozó, gazdasági rendeltetésű objektumot tártak fel. ${ }^{14}$ Tolna megyei régészeti terepbejárások során, az elpusztult középkori templomok közvetlen környezetében több helyen is (Gyapán, Anyán, Györkén) azonosítani lehetett egy további kő- vagy téglaépületet is, feltehetőleg a falu plébániáját, vagy nemesi kúriát. ${ }^{15} \mathrm{~A}$ gyapai lakóépület a templomdombtól 20 méterre, egy másik kiemelkedésen helyezkedett el, az építési törmelék közt szemeskályha-töredékeket találtak. ${ }^{16} \mathrm{~A}$ hidasi Kirchhofäckeren a két elkülönülő törmelékes folt egyikén könyvveretet találtak. ${ }^{17}$ Feltárások híján ezeknek az építményeknek a datálása sajnos bizonytalan. Terepbejárási adatok alapján az őcsényi pusztatemplom déli szomszédságában helyezkedett el a falu legrangosabb épülete kályhaszem töredékekkel és osztrák import kerámiával. ${ }^{18}$ Harc-Janyapusztán egy gótikus templomot és tőle nyugatra egy nagyobb kiterjedésú, négyzet alakú épületegyüttest sikerült azonosítani légifotózás segítségével; mindkét épület ugyanazon a kiemelkedésen állt. ${ }^{19} \mathrm{Az}$ utóbbi példák már a késő középkor időszakába vezetnek, de jól mutatják, hogy a templomok közelsége milyen fontos szerepet játszott a legelőkelőbb laikus és egyházi építmények pozicionálásában. Érdemes megvizsgálni közelebbről a plébániatemplomok, a településszerkezet és a társadalmi hierarchia összefüggéseit.

\section{A plébániatemplomok helye és szerepe a középkori faluszerkezetben}

Középkori településeken a templomépület, legyen az kőből, vagy fából, már a legkorábbi időkben kiemelkedett megjelenésével a környező épületek közül. Általában dombra épült, központi szerepét már a helykiválasztással hangsúlyozták. A lakóépítményekhez képest jóval időt állóbb létesítmény, kifejezi a helyi közösség, vagy nemes úr gazdasági és demográfiai erejét. Közösségi teret formáz, hozzá kapcsolódik a vallásos gyakorlat. A templom körüli temető a közösség kontinuitását fejezi ki.

A középkori településtörténet, településhálózat kutatásában az egyházi szervezet elemeinek, különösen a templomos helyek azonosítása mindig fontos szerepet játszott. A történeti monográfiák az írott források, vagy újkori térképi ábrázolások maximális kiaknázására törekedtek. ${ }^{20} \mathrm{Az}$ egyre bővülő régészeti forrásbázis interpretálása új szempontokat és eredményeket hozott. Az esetenként írott forrásokban is említett, elpusztult települések gyakran szintén elpusztult, de romjaiban, vagy felszíni maradványaikban kutatható templomaik révén meglehetősen jól azonosíthatók. Az egyházi topográfia külön témájává vált a középkori régészetnek; kisebb-nagyobb tájegységek középkori településtörténetének rekonstruálásához az egyházas helyek feltérképezése kiindulópontul szolgálhat. ${ }^{21} \mathrm{~A}$ mai Pest területének kora Árpád-kori településhálózatát elsősorban a korabeli templomos helyek összegyűjtésével rekonstruálta Irásné Melis Katalin. ${ }^{22}$ Egyes régiókban, így például Pest megyében, a középkori templomok régészeti kutatása egykori települések létére, a településhálózatra vonatkozóan is olyan új adatokat szolgáltatott, amelyek az írott forrásokból megrajzolható képhez képest jóval részletesebb rekonstruálást tettek lehetővé. ${ }^{23} \mathrm{~A}$ középkori úthálózat feltérképezéséhez a középkori templomok szintén segítséget nyújtanak, mert a középkori nyomvonalak igen nagymértékben igazodtak a templomokhoz. ${ }^{24} \mathrm{~A}$ templomok szükségszerủen jól megközelíthetőek kellett legyenek, hogy alapvető funkciójukat elláthassák. Nem ritkán a templomok közvetlen környezetében tartották a heti vásárokat, és az esetek legnagyobb többségében itt helyezkedett el a plébános háza, mely szintén az egyház tulajdonában állt.

11 Wolf 1987-1989. 429.

12 Miklós 1991. 440.

13 Méri 1964. 27.

14 Kovalovszki 1969.

15 K. Németh 2011. 37-39.

16 RégKut 2002. 221.

17 RégKut 2008. 151.

18 Miklós 2002. 34.

19 Miklós 2002. 34-35.

20 Szabó 1969., Maksay 1971.

21 K. Németh 2010., Rosta 2004.

22 Irásné 1975.

23 Tari 1995. 144.

24 Stibrányi 2008. 
Fenti tanulmányokban közös tehát, hogy a településhálózat, vagy úthálózat rekonstruálásához használják alapvető kiindulási pontként a templomos helyeket. Egy kisebb területi egységre, az egyes falvak szintjére fókuszálva már jóval kevesebb vizsgálattal rendelkezünk, a középkori templom és falu kapcsolatára maximum utalás szintjén térnek ki az elemzések. Vecsésen egy egyszerú vizsgálattal tudtuk illusztrálni a templomoknak a település formálódásában játszott központi szerepét. ${ }^{25}$ Az Árpád-kor első harmadában csekély intenzitású, egyenetlenül szórt megtelepedési nyomokat lehetett kimutatni, második harmadától kezdődően a telepnyomok már egymás közelében sűrűsödtek, két nagyobb települési egységet alkotva. Mindkét települési egység centrumában egyegy elpusztult középkori templomot találunk. Ha a leletek számát vizsgáljuk, ismét azt az eredményt kapjuk, hogy a templomok felé közeledve vált egyre intenzívebbé a megtelepedés. Pest megye északi részén a településfejlödés hasonló modelljét dokumentálták. ${ }^{26}$ Vecsési példánk azt bizonyítja, hogy miután az egyház felépült, a lakóépítmények igyekeztek a központi építmény közelébe húzódni, a szórványos megtelepedések pedig idővel elsorvadtak. A templom ebből kifolyólag gyújtópontjává vált a falusias település további fejlődésének. Természetesen a stabilizálódás, centralizálódás folyamata nem állította meg teljesen a kisebb települési egységek kirajzását. ${ }^{27}$

Az Árpád-kor első felében igen nehéz írott forrásokkal dokumentálni a templomépítő tevékenységet és különösen azt, hogy kik voltak ennek kezdeményezői. A királyi alapítások mellett az egyes faluközösségek is vállalkozhattak a feladatra, gazdasági erejük függvényében. Az első falusi templomok a püspökök fennhatósága alá tartoztak. Már a 11. századtól számolnunk kell magánegyházakkal. ${ }^{28} \mathrm{Az}$ Árpád-kor második felétől, a világi magánbirtok megerősödése után az építtetők közt a birtokos réteg, nemesi családok döntő szerepét kell kiemelni ${ }^{29}$, akik kisebb-nagyobb birtokközpontjaikban emeltek egyházakat, ezáltal a teljes uradalom egy plébániatemplom körzetének számított. A templom és a társadalmi elit közötti szoros térbeli kapcsolat nem véletlen: a feudális úr tulajdonosi jogait egyaránt kiterjesztette a földekre, azok megmúvelőire és a templomokra is (Eigenkirche, Patronatskirche). A templom és temető jogi aktusok tárgyává vált. A földesúr, bizonyos esetekben maga az alapító, fenntartotta magának az egyházi személyzet kinevezési jogát, a templommal pedig saját reprezentációs céljait szolgálta. A vallásgyakorlat alatt és halála után is megkülönböztetett hely illette meg a templomon belül. Falusias településeken a megtelepedés szempontjából a templom környezete az egyik legkívánatosabb helyszín lehetett. Régészeti adataink is azt erősítik meg, hogy a magasabb társadalmi ranggal bíró lakosok a megszentelt terület közelébe húzódtak.

\section{Egy esettanulmány: ásatások Dabason}

2007-2008 telén, majd 2010-ben Dabason (2. kép), több különböző építőipari beruházás kapcsán, egy középkori település nagyobb részleteit tárhattuk fel. ${ }^{30} \mathrm{~A}$ városba vezető új bekötőút feltárása a középkori település perifériájának kutatását tette lehetővé (54544, 54555 lelőhelyek), pár száz méterrel északabbra, további mintegy 1000 középkori régészeti objektumot bontottunk ki, köztük 10 földbe mélyített és több földfelszíni cölöpépítményt, melyek a település késő középkori magját képezhették (3. kép). A falunak ezt a részét tűzvész pusztította el a 14. században, a leégett építmények és leletek in situ maradtak ránk. Két házcsoportot különíthetünk el, egyet a felület délnyugati, egyet az északkeleti részén, a közöttük elhaladó út egyenesen a középkori templom felé tartott. A felület északkeleti része érdekes a jelen vizsgálat szempontjából. Az égésnyomok alapján azonos pillanatban pusztulhatott el a 223., a 270., 280., 310. ház. A 666. műhely, a 600. és a 650. bizonytalan funkciójú építmények szintén a 13-14. században funkcionáltak. A 270. (4. kép), 280., 310. egyosztatú, földbe mélyített, cölöpszerkezetes, kerek sütőkemencével ellátott házak körülvették a náluk kétszer nagyobb, feltehetően kétosztatú, pincével ellátott, szemeskályhával kifütött 223. házat (5. kép).

Igen szembeötlő a különbség a 223. és az azt körülvevő házak közt, ha a leletanyag mennyiségét és minőségét vizsgáljuk. Az egyszerübb kivitelú építmények néhány tucatnyi fazék-, palack-, esetleg pohár-, vagy szilketöredékével szemben a 223. házban ennek a 10-20-szorosa került elő; az előbbi edénytípusok mellett a háztartás kerámia eszközkészletéhez többféle kancsó, szűrő, lábos, nagyméretű tárolóedény és fedő tartozott, valamint egy osztrák import mesterjegyes fazék. A kerámiaanyag túlnyomó részét a szemeskályha cseréptöredékei tették ki. Előkerült itt továbbá több belső mázas edénytöredék, míg a többi házból csak a 270. tartalmazott egy hasonló darabot. Csak ebben a házban találtunk üvegpohár töredékeket és díszítő funkciójú ezüst- és bronzlemezeket. A házakból rendszerint egy-egy patkó, lakat, késpenge, szögek, vagy vaspántok kerültek elö, a 223. házban egy vaseszközökből álló depólelet is volt. A településen könyvveretek, ólomplombák, nemesfémmel díszített tárgyak, illetve egy velencei aranydukát is előkerült, ezek a tárgyak a falu vezetőinek különleges státuszára utalnak.

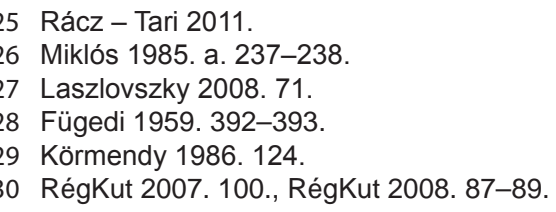




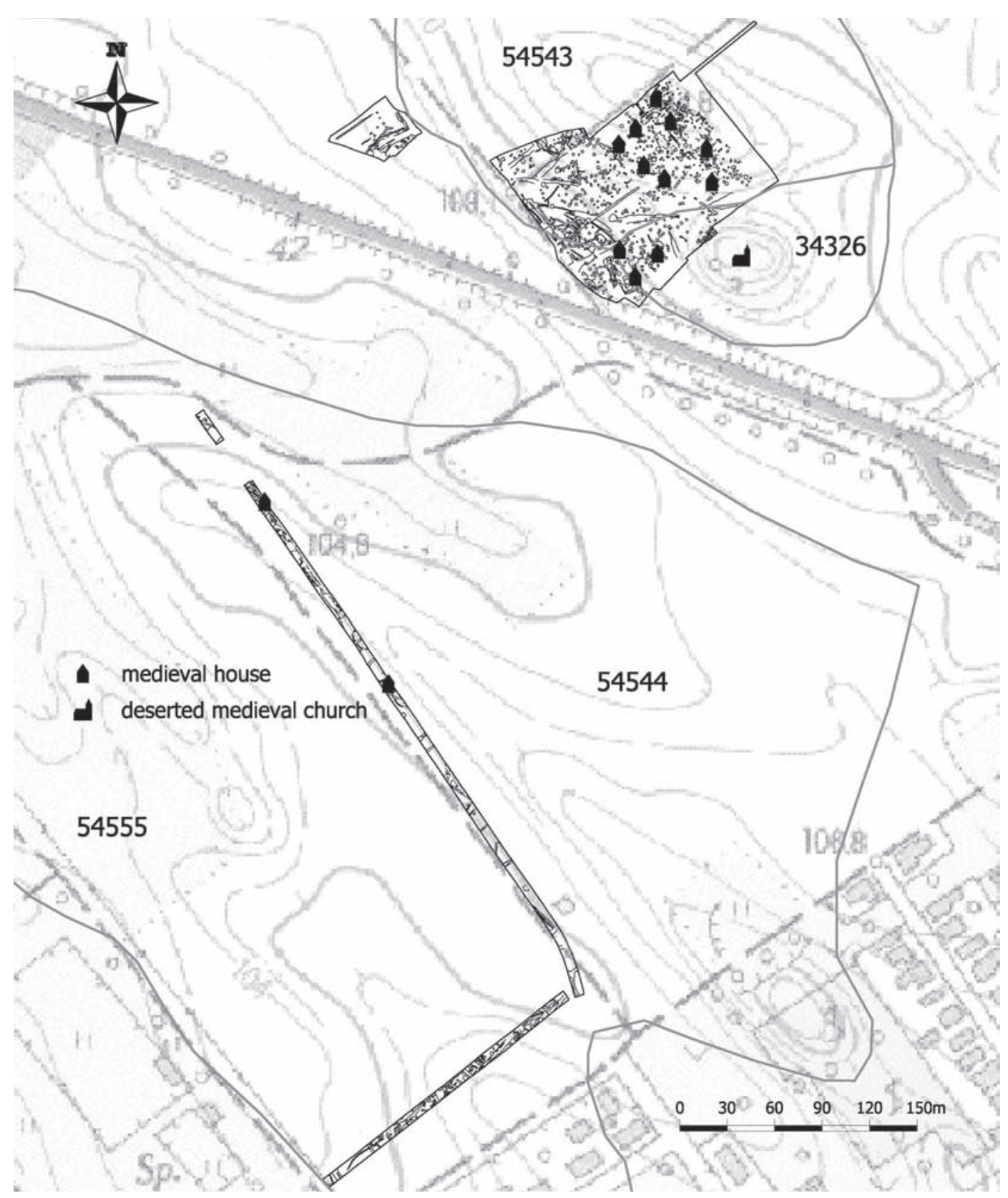

2. kép: Régészeti feltárások Dabason. A középkori házak a pusztatemplom körül sürüsödnek

\section{Összefoglaló megjegyzések}

A dabasi középkori település szerkezetét illetően három aspektust kell kiemelnünk: a korai időszakhoz képest a 13-14. századi településrészlet koncentráltabb struktúrát mutat, ez a későbbi, már falunak nevezhető egység a templom közvetlen közelében található, továbbá, a legnagyobb, legrangosabb lakóépítmény maga köré szervezi, maga alá rendeli a többi építményt. A vecsési és dabasi települések szerkezeti átalakulása és térbeli újrarendeződése általános érvényű átalakulási folyamatokat tükröznek.

A legkorábbi időszakban (10-11. század) a lakóépítmények elhelyezkedése a termőföld optimális kihasználásának volt alárendelve. A szántók gyors kimerülése, az új földek feltörése miatt természetes és folyamatos volt a lakóépítmények költözése a falu határain belül, ami szórt településszerkezetet eredményezett. Az új technológiák bevezetésével átalakul ez a termelői rendszer, elterjed a szabályozott talajváltó gazdálko- 


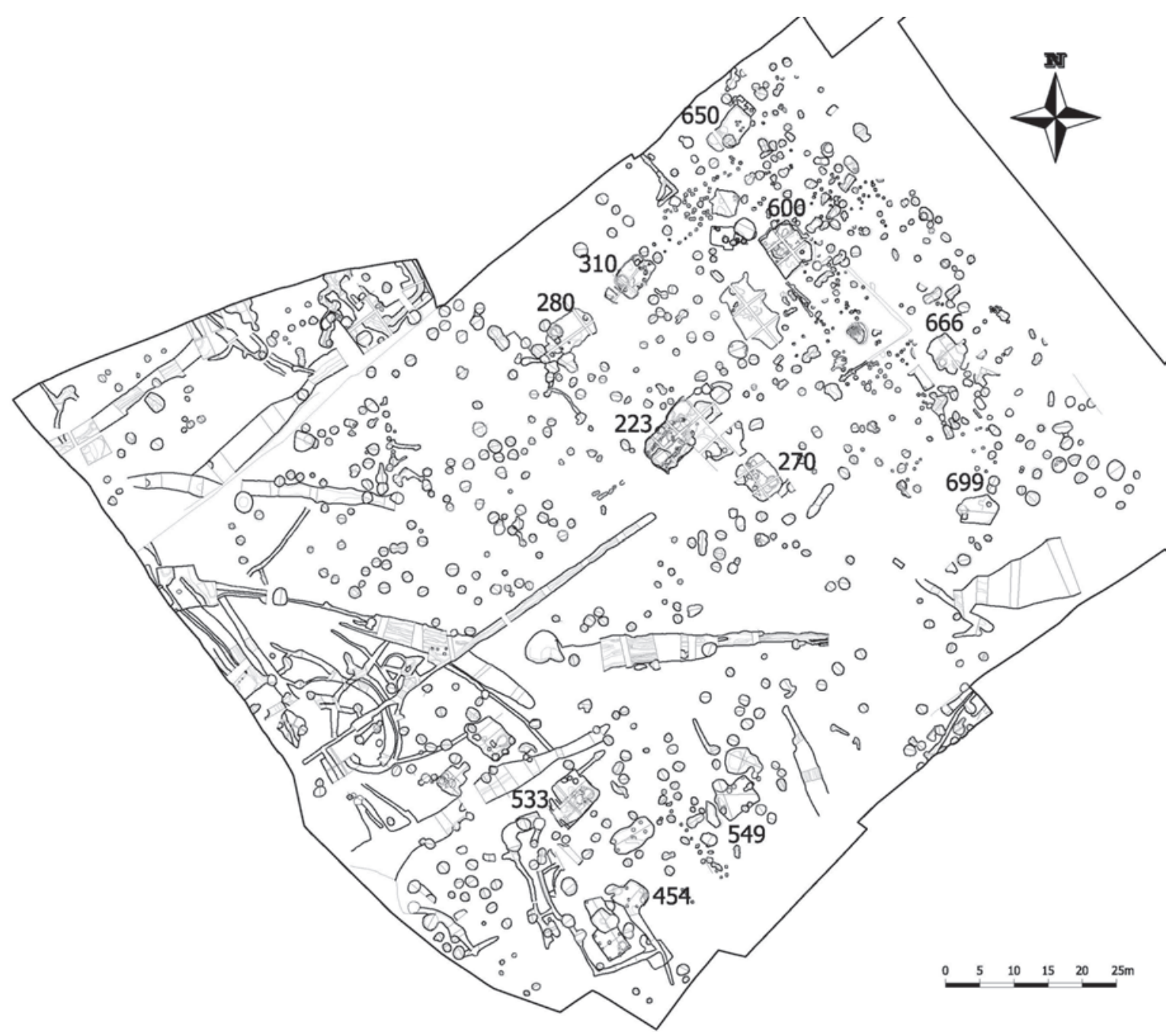

3. kép: Dabas középkori falujának központi magja. A földbe mélyített építmények körülveszik a lelöhely legnagyobb és leggazdagabb épittményét (223. objektum)

dás. Megindul a jogilag egységes jobbágyság kialakulása is és mindez elősegíti a telkek rögzülését, a települések stabilizálódását. ${ }^{31}$ Az agrártechnikai fejlődéssel és társadalmi átalakulással párhuzamosan, a 13. században egy másik lényeges folyamat is lejátszódik: ugrásszerúen megnő a templomok száma és a rögzülő települések hálózata stabil plébániahálózattal egészül ki. A templom lesz a szabályos szerkezetű falu központi építménye, a település magja. Ugyanezt a központosuló folyamatot gyorsítja az egyre erősebb kézmúvesipari szakosodás, a piacra termelés. Valószínúleg nem tudjuk feltárni azon tényezők összességét, melyek létrehoztak egy-egy települést és determinálták fejlődését. A gazdasági termelői rendszer, a természetföldrajzi adottságok, a meglévő település- és úthálózat voltak talán a legfontosabb formáló erők. ${ }^{32}$ Az egyes értékelések során azonban érdemes tekintetbe venni a templom pozícióját és korát, valamint a társadalmi hierarchia lehetséges nyomait is. Mindezek mellett létezhettek olyan egyéni preferenciák, mint például egy földbirtokos telepítési szempontjai, melyekről részletesebb tájékoztatást nem adhatnak a forrásaink.

A 14. század előtti magyar társadalom változásait nem, vagy alig tudjuk megragadni a települések régészeti hagyatékában, pedig az 1000. év körül egy teljesen új rend született. Szent István király megkoronázása alapvető változásokat indított el: a közösségi birtoklás visszaszorult a magántulajdon javára, a mezőgazdaság egyre nagyobb hangsúlyt kapott az állattenyésztéshez képest, és a szabad közösségeket lassan felváltották az alávetett csoportok. Joggal vethetjük fel a kérdést: miért nem találjuk az Árpád-kori társadalmi tagozódás régészeti emlékeit? A jelenségre több lehetséges magyarázat is felmerül: 
- A középkori falvakról való jelenlegi tudásunk nincs összhangban a rendelkezésünkre álló forrásanyaggal a nagy felületű feltárások adatainak nem megfelelő ütemű feldolgozása miatt. A strukturálatlan adathalmaz kiértékelése még számtalan értékes adatot eredményezhet.

- Talán elfogadhatjuk, hogy a földbe mélyített építmények nagy része az írott források mansiunculá-jával azonosítható. A többi háztípus, az előkelőbb társadalmi csoportok lakhelye feltehetően jórészt a földfelszínre épült, és nyomok nélkül elpusztult.

- Már a 80-as években felmerült, hogy az előkelők egy részének lakhelyéül az ún. „kisvárak” is szolgálhattak, legalábbis egyik csoportja a kisváraknak. ${ }^{33} \mathrm{~A}$ korai földesúri erődítmények rendszerezésében, keltezésében azonban még nem jutott konszenzusra a kutatás, tulajdonosi körére vonatkozó viták sem zárultak le.

- A településhálózatban az urbanizáció korai fázisa csak a 13. században jelenik meg, mikor a piacgazdaság és kereskedelem nagyobb hangsúlyt kap. A települések külső képe ekkortól változhat lényegesen. Addig viszont az egységes faluképet talán nem is színezte annyi eltérő minőségú építmény, hogy az megjelenjen ásatási adatainkban.

A közemberek változatos társadalmi csoportokba tartoztak, de megélhetésüket szinte kivétel nélkül a mezőgazdaság és állattenyésztés biztosította, és ez a meglehetősen zárt, önfenntartó termelői rendszer azonos külső megjelenésű falusias településeket, lakóépítményeket eredményezett. Igen szerencsésen világítja meg ezt a körülményt egy 13. századi írott forrásunk. Margit szentté avatási jegyzőkönyvében olvashatunk a Pesti Síkságra lokalizálható Nevegyen megesett csodáról, melynek kapcsán Tárnoki Miklós családjának életébe is bepillantást nyerhetünk. ${ }^{34} \mathrm{~A}$ családfő még az őszi éjszakán is házon kívül, az állatokkal aludt, míg az anya két gyerekével az egyosztatú, belülről zárható lakóházban, melynek közepén helyezkedett el a tüzhely. Társadalmi pozíciójukra is fény derül a tanúkihallgatások során: egyértelmúen a szabadok (liber) közé tartoznak, ráadásul a tehetősebbek közé. Legközelebbi szomszédaik viszont Veligh úr szolgái voltak.

Érdemes a fentiekhez még egy ásatásból származó adatot is idézni. A tápiógyörgyei llike parton feltárt, a 13. században leégett, földbe mélyített lakóépítmény járószintjén több tucatnyi fémeszköz került elő: leginkább mezőgazdasági és háztartási eszközök, de volt itt egy ép kandeláber, sodronypáncél töredéke, tőr és több ládavasalat is. ${ }^{35} \mathrm{~A}$ ház maga a templom körüli temetőben, a templomtól $2,7 \mathrm{~m}$-re helyezkedett el. Leletei és pozíciója révén kiemelt jelentőségú épület kellett legyen a településen belül - bár azt nem lehet eldönteni, hogy a plébános lakóháza volt-e, vagy egy olyan építmény, ahol a lakosság és az egyház értékeit helyezték el vész esetén. A ház méreteit, szerkezetét tekintve ugyanakkor tökéletesen illeszkedik a 13. századi, földbe mélyített lakóépítmények sorába, azaz pusztán a külső megjelenése nem jelezte volna számunkra az építmény speciális jellegét, vagy lakójának státusát.

Az Árpád-kor végén az emberi közösségek szűkebb területre koncentrálódása, ennek a szűkebb területnek (falunak) szabályos, vagyis többé-kevésbé tervezett belső felosztása nyilvánvalóan újradefiniálta a faluközösséget, az emberi kapcsolatokat is. A társadalmi alá- és fölérendeltségi viszonyok a település belső képében is megjelentek és a 13., de különösen a 14. századtól, a föld birtokjogának változásai és az egységes jobbágyság kialakulása után látványos kifejeződésre juthattak. A templom és vele együtt a vallási gyakorlat, mint a település formálódását meghatározó faktor ugyanakkor jól mutatja, hogy a középkori közösséget nem csak a környezeti, vagy termelői-gazdasági viszonyok, hanem az ideológiai-kulturális tényezők egyaránt kondicionálták.

\section{Összefoglalás}

Az államalapítás utáni írott források lehetővé tették az Árpád-kori társadalom rekonstruálását, de ennek a rendkívül színes világnak a régészeti hagyatékát nem sikerült még a társadalmi csoportok szerint differenciálni. Jelen tanulmány a településrégészet adatainak társadalomtörténeti jellegű értelmezésére törekszik föleg Pest megyei feltárások és terepbejárások felhasználásával. Az Árpád-korban a leletanyagban, az építészeti megoldásokban, esetleg a településszerkezetben kereshetjük a társadalmi elkülönülés jeleit. A társadalmi csoportok írott forrásokból ismert változatossága azonban mintaterületünk falusias településein alig jelent meg, és ez általában érvényesnek tekinthető a középkori Magyarország teljes területére nézve is. A társadalmi alá- és fölérendeltségi viszonyok a települések belső képében csak a 13., de különösen a 14. századtól, a föld birtokjogának változásai és az egységes jobbágyság kialakulása után jutottak látványos kifejeződésre. Régészeti adataink több esetben is azt erősítették meg, hogy a magasabb társadalmi ranggal bíró lakosok a templomok közelében telepedtek meg.

33 Miklós 1985. b. 152.

34 Laszlovszky 2011

35 Dinnyés 1994. 

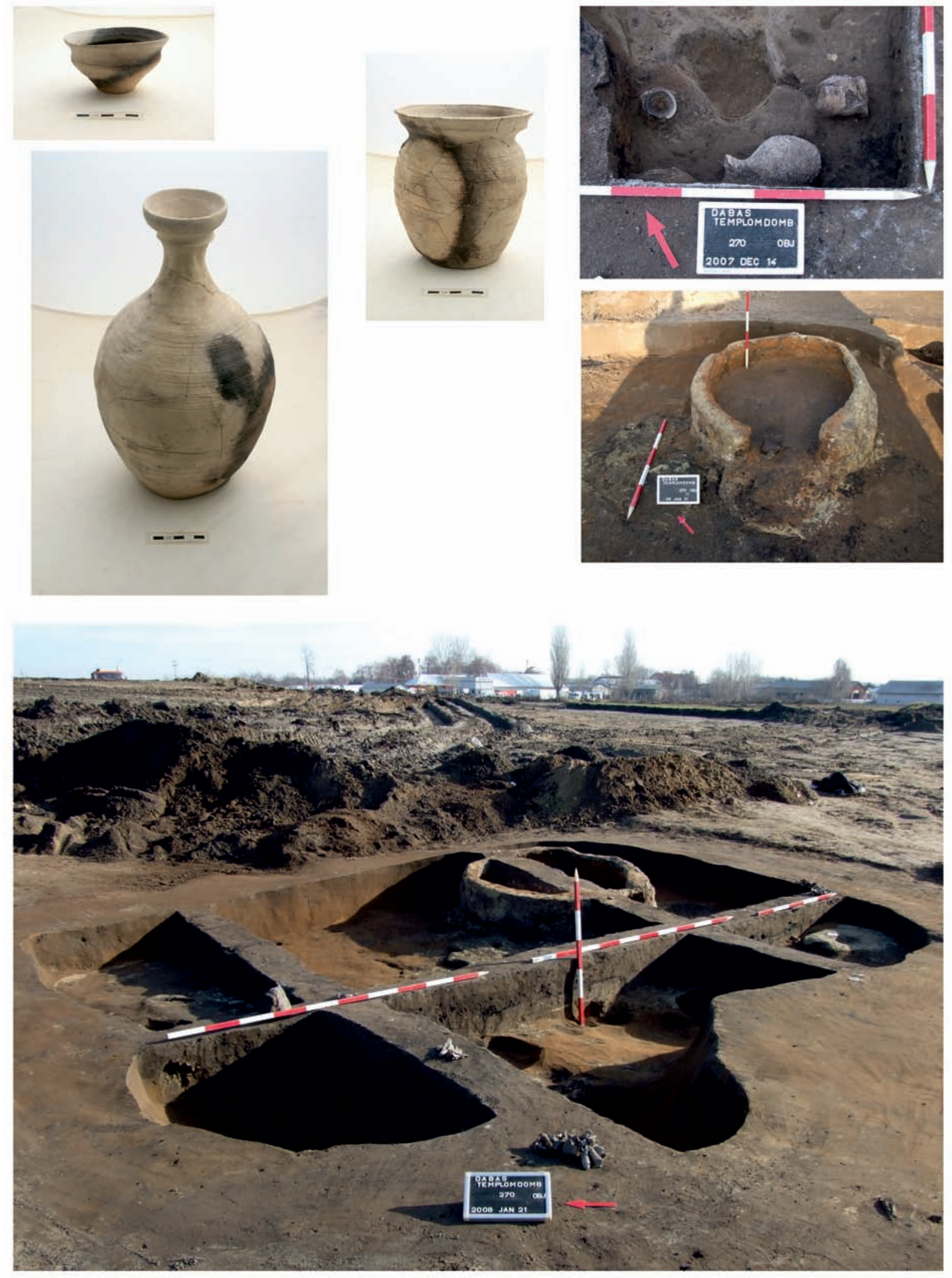

4. kép: Az egyosztatú, földbe mélyített 270. ház fotói és leletei. A padlón in situ találtuk meg a 13-14. század jellegzetes edényeit 

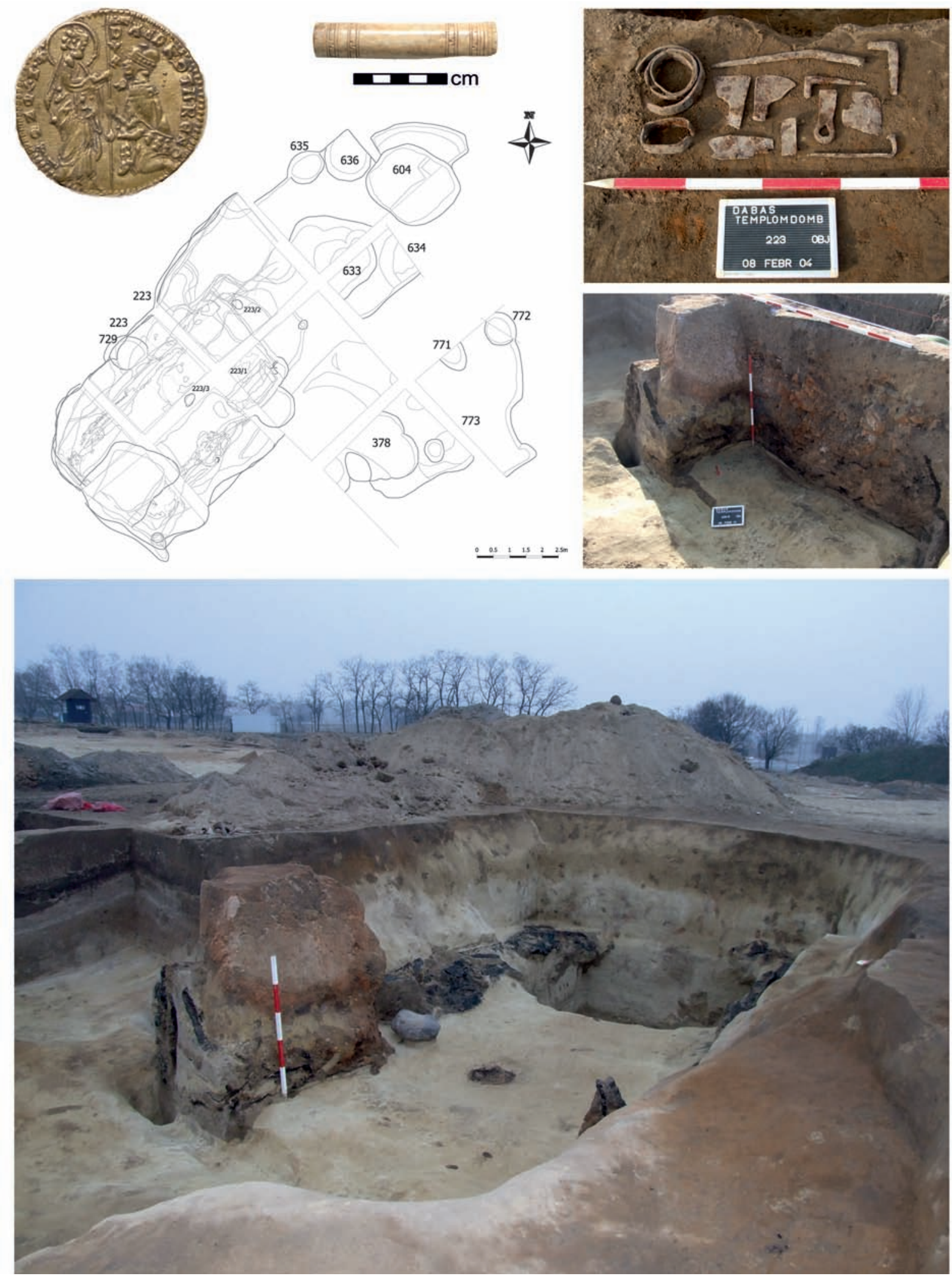

5. kép: A 223. objektum alaprajza és fotói. A pince gödrének hosszanti oldalait deszkaborítás fedte.

A nagy alapterületü beásás közepén találtuk meg a szemeskályha omladékát. A vas depólelet és a bekarcolással díszített csonttárgy a betöltésböl származik. Andrea Contarini (1367-1382) velencei dózse arany dukátja szórványként került elő a lelöhely területéröl 


\title{
Social differences within 10th-14th centuries rural settlement types in the central area of the Hungarian Kingdom
}

\author{
TIBOR ÁKOS RÁCZ
}

The social categories of lower and middle classes in the 10th-14th centuries Hungary were divided into several different communities according to their legal and tenurial status and possessions, but almost all of them lived in agricultural rural settlements. The balance of different economical, ecological, social and cultural forces defined the appearance and everyday life of a historical settlement, and their changing intensity resulted in different subsistence strategies for each community. Archaeological research described the main characteristics of medieval rural settlement structures, and for their interpretation historical evidences were presented too, but beyond the identification of the few basic types (dispersed structure, hamlets and nucleated villages) hardly any specific conclusions were made, and the evaluation of the sites remained on the level of generalities. Every single case deserves individual evaluation of possible formative factors. We need to describe models which concentrate not only on the number and density of houses, but which try to reveal the social, economical, ecological aspects of the habitation, too. The present paper with the help of recent archaeological evidences from Pest County examines the way social differences and the position of the church affected the formation of the medieval rural settlement structures.

\section{Irodalom}

Belényesy M. 1960.: La culture permanente et l'evolution du système biennal et triennal en Hongrie medièvale. Ergon 2. 311-326.

Bóna I. 1998.: Az Árpádok korai várai. Debrecen

Buzás G. - Mészáros O. 2008.: A középkori Visegrád egyházainak régészeti kutatása. Magyar Sion Új folyam 2. (44) 71-103.

Dinnyés I. 1994.: XIII. századi ház a tápiógyörgyei Ilike parton (Ein Haus aus dem 13. Jahrhundert am Ufer von Ilike in Tápiógyörgye). Studia Comitatensia 23. 101-118.

Fodor I. 1989.: Megjegyzések a középkori magyar lakóház fejlődéstörténetéhez (Anmerkungen zur Entwicklungsgeschichte des ungarischen Wohnhauses im Mittelalter). In.: Népi építészet a Kárpát-medence északkeleti térségében. Szerk.: Cseri Miklós - Balassa M. Iván - Viga Gyula, Miskolc - Szentendre, 21-45.

Freisingi O. 2000.: I. Frigyes császár tettei. In.: Magyar történeti szöveggyűjtemény, 1000-1526. Szerk.: Bertényi Iván, Budapest

Fügedi E. 1959.: Kirchliche Topographie und Siedlungsverhältnisse im Mittelalter in der Slowakei. Studia Slavica Academiae Scientiarum Hungaricae V. 363-400.

Irásné M. K. 1975.: Középkori falvak Pest határában (Mittelalterliche Dörfer in der Gemarkung von Pest). Archaeologiai Értesítö 102. 224-243.

Kovalovszki J. 1969.: Ásatások Csepelyen (Ausgrabungen in Csepely). Veszprém Megyei Múzeumok Közleményei 8. 235 -252.

K. Németh A. 2010.: A középkori Magyarország egyházi topográfiai kutatása. Kutatástörténeti áttekintés (Topographical Research Concerning the Church in Medieval Hungary. A Review of the Research). In.: A középkor és a kora újkor régészete Magyarországon. Szerk.: Benkő Elek - Kovács Gyöngyi, Budapest, 271-287.

K. Németh A. 2011.: A középkori Tolna megye egyházi topográfájának módszertani tapasztalatai. In.: Fél évszázad terepen. Tanulmánykötet Torma István tiszteletére 70. születésnapja alkalmából. Szerk.: Kővári Klára - Miklós Zsuzsa, Budapest, 35-42.

Körmendy A. 1986.: A falusi plébániák hatása a faluközösség kialakulására. A Szepesség példája. In.: Művelődéstörténeti tanulmányok a magyar középkorról. Szerk.: Fügedi Erik, Budapest, 117-158.

Laszlovszky J. 1999.: Field Systems in Medieval Hungary. In.: The Man of Many Devices, Who Wandered Full Many Ways. Festschrift in Honor of János M. Bak. Eds.: Nagy, Balázs - Sebők, Marcell, Budapest, 432-444.

Laszlovszky J. 2008.: Földművelés a késő középkori Magyarországon. In.: Gazdaság és gazdálkodás a középkori Magyarországon. Gazdaságtörténet, anyagi kultúra, régészet. Szerk.: Kubinyi András - Laszlovszky József - Szabó Péter, Budapest, 49-82.

Laszlovszky J. 2011.: Fama sanctitatis and the Emergence of St. Margaret's Cult in the Rural Countryside. The Canonozation Process and Social Mobility in Thirteenth-Century Hungary. In.: Promoting the Saints. Cults and Their Contexts from Late Antiquity until the Early Modern Period. Essays in Honor of Gábor Klaniczay for His 60th Birthday. Eds.: Gecser, Ottó - Laszlovszky, József - Nagy, Balázs - Sebők, Marcell - Szende, Katalin, Budapest - New York, 103-123. 
Maksay F. 1971.: A magyar falu középkori településrendje. Budapest

Maksay F. 1978.: Das Agrarsiedlungssystem des mittelalterlichen Ungarn. Acta Historica 24. 83-108.

Méri I. 1952.: Beszámoló a Tiszalök-rázompusztai és Túrkeve-mórici ásatások eredményeiről. Archaeologiai Értesítő 79. 49-67.

Méri I. 1964.: Árpád-kori népi építészetünk feltárt emlékei Orosháza határában. Régészeti Füzetek Ser II. 12. Budapest

Miklós Zs. 1985. a.: Einige Fragen der mittelalterlichen Siedlungsgeschichte im Spiegel der archäologischen Topographie. Mitteilungen des Archäologischen Instituts der Ungarischen Akademie der Wissenschaften 14. 235-242.

Miklós Zs. 1985. b.: Árpád-kori kisvárak Magyarországon [Arpadenzeitliche (12-14. Jh.) Kleinburgen in Ungarn]. In.: Középkori régészetünk újabb eredményei és időszerű feladatai. Szerk.: Fodor István - Selmeczi László, Budapest, 143-158.

Miklós Zs. 1991.: XIII. századi nemesi udvarház Tura-Szentgyörgyparton (Der Herrenhof von Tura-Szentgyörgypart aus dem XIII. Jahrhundert). Studia Comitatensia 22. 433-456.

Miklós Zs. 2002.: A légi fotózás szerepe a templomkutatásban. Két Tolna megyei középkori templom felfedezése. Műemlékvédelem XLVI/1. 30-35.

Rácz T. Á. 2010.: Árpád-kori települések szerkezetének sajátosságai Pest megyében. Kutatások az M0-s autópálya és a 4-es számú elkerülő főút nyomvonalában (Characteristics of the Structure of Árpádian-era Settlements. Investigations Along the Line Followed by the M0 Motorway and the Highway 4 Bypass). In.: A középkor és a kora újkor régészete Magyarországon. Szerk.: Benkő Elek - Kovács Gyöngyi, Budapest, 69-79.

Rácz T. Á. - Tari E. 2011.: Topográfiai kutatások Vecsésen. Árpád-kori települési formák régészeti terepbejárások és feltárások alapján. In.: Fél évszázad terepen. Tanulmánykötet Torma István tiszteletére 70. születésnapja alkalmából. Szerk.: Kővári Klára - Miklós Zsuzsa, Budapest, 53-76.

RégKut: Régészeti kutatások Magyarországon (Archaeological Investigations in Hungary). Budapest

Rosta Sz. 2004.: Pusztatemplomok Kiskunfélegyháza környékén (Pusstakirchen in der Umgebung von Kiskunfélegyháza). Cumania 20. 113-172.

Simonyi E. 2003.: Beszámoló az M0. autóút Gyál 3. és Gyál 10. lelőhelyén feltárt Árpád-kori lakóházakról (Account on the Arpadian Age dwelling houses explored in Gyál 3 and Gyál 10 along Motorway M0). Békés Megyei Múzeumok Közleményei 24-25. 353-374.

Steuer, H. 1982.: Frühgeschichtliche Sozialstrukturen in Mitteleuropa. Göttingen

Stibrányi M. 2008.: A Sárvíz középkori településhálózatának vázlata, avagy a templom és a hozzá vezető út. Alba Regia 37. 189-196.

Szabó I. 1963.: A prédium. Vizsgálatok a korai magyar gazdaság- és településtörténelem körében (Das praedium. Untersuchungen im Bereich der frühen ungarischen Wirtschafts- und Siedlungsgeschichte). Agrártörténeti Szemle 5. 1-49., 301-337.

Szabó I. 1969.: A középkori magyar falu. Budapest

Szűcs J. 1981.: Megosztott parasztság - egységesülő jobbágyság: a paraszti társadalom átalakulása a 13. században. 1-2. Századok 115. 3-65., 263-314.

Takács M. 2000.: Nucleated and/or dispersed settlements from the Árpádian and Angevin age in the West Hungarian region of Kisalföld. Ruralia III., Památky Archeologické - Supplementum 14., Praha, 240-251.

Takács M. 2001.: AzÁrpád-kori köznépi lakóház kutatása, különös tekintettel az 1990-es évekre (Erforschung desWohnhauses des gemeinen Volkes zur Arpadenzeit; im Mittelpunkt die Forschung der 1990er Jahre). In.: Népi építészet a Kárpátmedencében a honfoglalástól a 18. századig. Szerk.: Cseri Miklós - Tárnoki Judit, Szentendre-Szolnok, 7-54.

Tari E.1995.: Árpád-kori falusi templomok Cegléd környékén. Cegléd

Wolf M. 1987-1989.: Előzetes jelentés a borsodi földvár ásatásáról (1987-1990) [Vorläufiger Bericht über die Ausgrabung der Erdburg von Borsod (1987-1990)]. Jósa András Múzeum Évkönyve 30-32. 393-442.

Závodszky L. 1904.: A Szent István, Szent László és Kálmán korabeli törvények és zsinati határozatok forrásai. Függelék: a törvények szövege. Budapest 